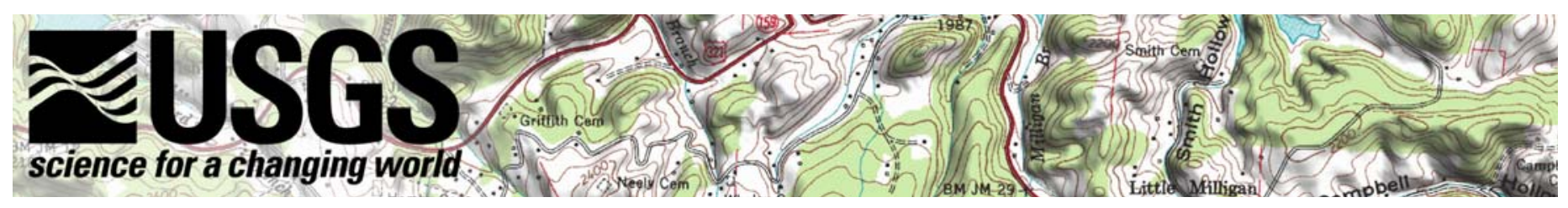

\title{
The National Map - Geographic Names
}

\section{The Nation Needs The National Map}

Governments depend on a common set of base geographic information as a tool for economic and community development, land and natural resource management, and health and safety services. Emergency management and homeland security applications rely on this information. Private industry, nongovernmental organizations, and individual citizens use the same geographic data. Geographic information underpins an increasingly large part of the Nation's economy.

Available geographic data often have the following problems:

Do not align with each other because layers are frequently created or revised separately,

Do not match across administrative boundaries because each producing organization uses different methods and standards, and

Are not up to date because of the complexity and cost of revision.

The U.S. Geological Survey (USGS) is developing The National Map to be a seamless, continuously maintained, and nationally consistent set of online, public domain, geographic base information to resolve these issues. The National Map will serve as a foundation for integrating, sharing, and using other data easily and consistently.

In collaboration with other Federal, State, county, and local government agencies, the private sector, academia, and the public, the USGS will coordinate, integrate, and, where needed, produce and maintain base geographic data.
The National Map will include digital orthorectified imagery, elevation data, vector data for hydrography, transportation, boundary, and structure features, geographic names, and land cover information. The data will be the source of revised paper topographic maps.

\section{Geographic Names}

The Geographic Names Information System (GNIS), developed by the USGS in cooperation with the U.S. Board on Geographic Names (USBGN), contains information about the proper names for places, features, and areas in the 50 States, the District of Columbia, and the territories and outlying areas of the United States, as well as for Antarctica. It is the geographic names component of The National Map.

The GNIS contains records on almost 2 million geographic names in the United States-from populated places, schools, reservoirs, and parks to streams, valleys, springs, ridges, and every feature type except roads and highways. Entries include information such as the federally recognized name and variant spellings for the feature; former names; the status of the name as determined by the USBGN; the county or counties in which each named feature is located; the geographic coordinates that locate the approximate center of an areal feature or the mouth and source of a linear feature, such as a stream; and the name of the cell of the USGS topographic map or maps on which the feature may appear. Elevation, size, and historical information are available for some features, as is a bibliographic code for the source of information. Data from the GNIS are used for emergency preparedness, mapmaking, local and

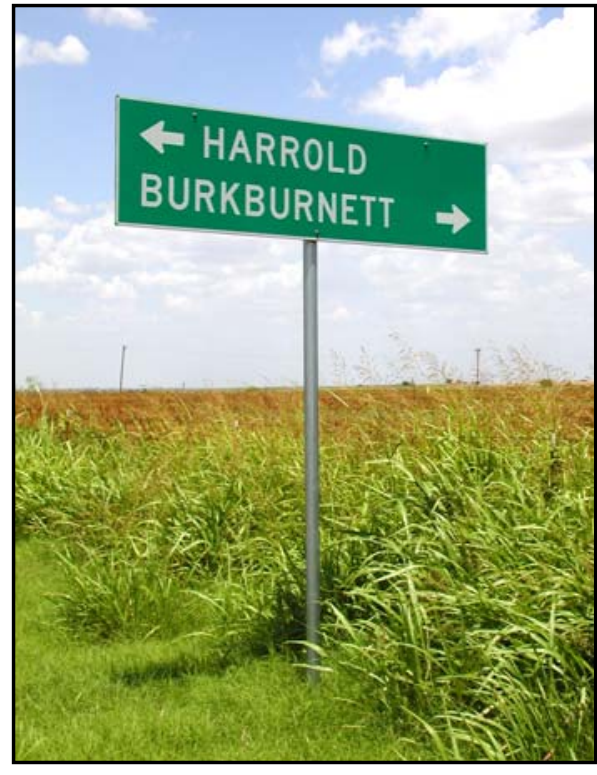

regional planning, service delivery routing, marketing, site selection, environmental analysis, genealogical research, and other applications.

\section{Data Availability}

Data for each State or territory are compiled in two phases. Phase One, which is complete, entailed the collection of most feature names from 1:24,000scale topographic maps published by the USGS and the U.S. Forest Service and from charts of the National Ocean Service. Phase Two is a long-term project to gather additional names from State and local materials and a variety of historical documents. This phase is accomplished on a State-by-State basis and is approximately 90 percent complete.

Responses to special requests for GNIS digital reports are available through file transfer protocol (FTP). Standard State and territory digital gazetteers also are available for downloading at the GNIS 
Web site by anonymous FTP. Special topical files are available at this site and include Populated Places (all populated place records in the GNIS), Concise (major features) and Historical (features that no longer exist).

\section{Partnership Opportunities}

The BGN maintains working relationships with State names authorities in order to cooperate in achieving the standardization of geographic names. In addition, other Federal agencies, such as the U.S. Forest Service, National Park Service, Bureau of Land Management, and U.S. Census Bureau submit geographic names information to continue the process of updating and refining the information in the GNIS.

Organizations interested in partnering with the USGS to develop geographic names data for The National Map should contact the USGS mapping liaison in their State. The list of liaisons is available at mapping.usgs.gov/ www.index\#partners. Click on "Mapping Partnership Program."

\section{Information}

Further information about The National Map is available from the Cooperative Topographic Mapping Program, Mail Stop 511, USGS National Center, 12201 Sunrise Valley Drive, Reston, VA 20192. You can view and download more information about The National Map at nationalmap.usgs.gov.

For more information on the GNIS or on individual State and territory database file status, contact:

\section{GNIS Manager}

U.S. Geological Survey

523 National Center

Reston, VA 20192

Phone: 703-648-4544

Fax: 703-648-4165

E-mail: GNIS_manager@usgs.gov

The address for the GNIS home page is geonames.usgs.gov.

For information on other USGS products and services, call 1-888-ASK-USGS or visit the general interest publications Web site on mapping, geography, and related topics at mac.usgs.gov/mac/isb/ pubs/pubslists/.

For additional information, visit the ask.usgs.gov Web site or the USGS home page at www.usgs.gov.

\begin{tabular}{|c|c|}
\hline Feature Name: & Catoctin Mountain \\
\hline Feature Type: & summit \\
\hline Elevation: & 1885 \\
\hline State & County \\
\hline Maryland & Frederick \\
\hline Virginia & Loudoun \\
\hline \multicolumn{2}{|r|}{ Variant Name(s) } \\
\hline \multicolumn{2}{|l|}{ Catoctin Mountains } \\
\hline \multicolumn{2}{|l|}{ Katoctin Mountain } \\
\hline \multicolumn{2}{|l|}{ Kittochiny Mountains } \\
\hline \multicolumn{2}{|l|}{ Kittockton Mountains } \\
\hline \multicolumn{2}{|l|}{ Kittoctin Mountain } \\
\hline \multicolumn{2}{|l|}{ Kittocton Mountain } \\
\hline \multicolumn{2}{|l|}{ South Mountain } \\
\hline $\begin{array}{l}\text { Latitude I Longitude } \\
\text { (nn'nn'nn"/nnn'nn'nn") }\end{array}$ & USGS $7.5^{\prime} \times 7.5^{\prime}$ Map \\
\hline $393852 \mathrm{~N} 0772800 \mathrm{~W}$ & Blue Ridge Summit \\
\hline $393500 \mathrm{~N} 0772900 \mathrm{~W}$ & Catoctin Furnace \\
\hline $393310 \mathrm{~N} 0773010 \mathrm{~W}$ & Myersville \\
\hline $392840 \mathrm{~N} 0773010 \mathrm{~W}$ & Middletown \\
\hline $392900 \mathrm{~N} 0772930 \mathrm{~W}$ & Frederick \\
\hline $391700 \mathrm{~N} 0773230 \mathrm{~W}$ & Point of Rocks \\
\hline $391040 \mathrm{~N} 0773440 \mathrm{~W}$ & Waterford \\
\hline
\end{tabular}

\begin{tabular}{|c|c|}
\hline Feature Name: & Catoctin Mountain \\
\hline Feature Type: & summit \\
\hline Elevation: & 1885 \\
\hline State & County \\
\hline Maryland & Frederick \\
\hline Virginia & Loudoun \\
\hline \multicolumn{2}{|r|}{ Variant Name(s) } \\
\hline \multicolumn{2}{|l|}{ Catoctin Mountains } \\
\hline \multicolumn{2}{|l|}{ Katoctin Mountain } \\
\hline \multicolumn{2}{|l|}{ Kittochiny Mountains } \\
\hline \multicolumn{2}{|l|}{ Kittockton Mountains } \\
\hline \multicolumn{2}{|l|}{ Kittoctin Mountain } \\
\hline \multicolumn{2}{|l|}{ Kittocton Mountain } \\
\hline \multicolumn{2}{|l|}{ South Mountain } \\
\hline $\begin{array}{l}\text { Latitude I Longitude } \\
\text { (nn'nn'nn"/nnn'nn'nn") }\end{array}$ & USGS $7.5^{\prime} \times 7.5^{\prime}$ Map \\
\hline $393852 \mathrm{~N} 0772800 \mathrm{~W}$ & Blue Ridge Summit \\
\hline $393500 \mathrm{~N} 0772900 \mathrm{~W}$ & Catoctin Furnace \\
\hline $393310 \mathrm{~N} 0773010 \mathrm{~W}$ & Myersville \\
\hline $392840 \mathrm{~N} 0773010 \mathrm{~W}$ & Middletown \\
\hline $392900 \mathrm{~N} 0772930 \mathrm{~W}$ & Frederick \\
\hline $391700 \mathrm{~N} 0773230 \mathrm{~W}$ & Point of Rocks \\
\hline $391040 \mathrm{~N} 0773440 \mathrm{~W}$ & Waterford \\
\hline
\end{tabular}

\begin{tabular}{|c|c|}
\hline Feature Name: & Catoctin Mountain \\
\hline Feature Type: & summit \\
\hline Elevation: & 1885 \\
\hline State & County \\
\hline Maryland & Frederick \\
\hline Virginia & Loudoun \\
\hline \multicolumn{2}{|r|}{ Variant Name(s) } \\
\hline \multicolumn{2}{|l|}{ Catoctin Mountains } \\
\hline \multicolumn{2}{|l|}{ Katoctin Mountain } \\
\hline \multicolumn{2}{|l|}{ Kittochiny Mountains } \\
\hline \multicolumn{2}{|l|}{ Kittockton Mountains } \\
\hline \multicolumn{2}{|l|}{ Kittoctin Mountain } \\
\hline \multicolumn{2}{|l|}{ Kittocton Mountain } \\
\hline \multicolumn{2}{|l|}{ South Mountain } \\
\hline $\begin{array}{l}\text { Latitude I Longitude } \\
\text { (nn'nn'nn"/nnn'nn'nn") }\end{array}$ & USGS $7.5^{\prime} \times 7.5^{\prime}$ Map \\
\hline $393852 \mathrm{~N} 0772800 \mathrm{~W}$ & Blue Ridge Summit \\
\hline $393500 \mathrm{~N} 0772900 \mathrm{~W}$ & Catoctin Furnace \\
\hline $393310 \mathrm{~N} 0773010 \mathrm{~W}$ & Myersville \\
\hline $392840 \mathrm{~N} 0773010 \mathrm{~W}$ & Middletown \\
\hline $392900 \mathrm{~N} 0772930 \mathrm{~W}$ & Frederick \\
\hline $391700 \mathrm{~N} 0773230 \mathrm{~W}$ & Point of Rocks \\
\hline $391040 \mathrm{~N} 0773440 \mathrm{~W}$ & Waterford \\
\hline
\end{tabular}

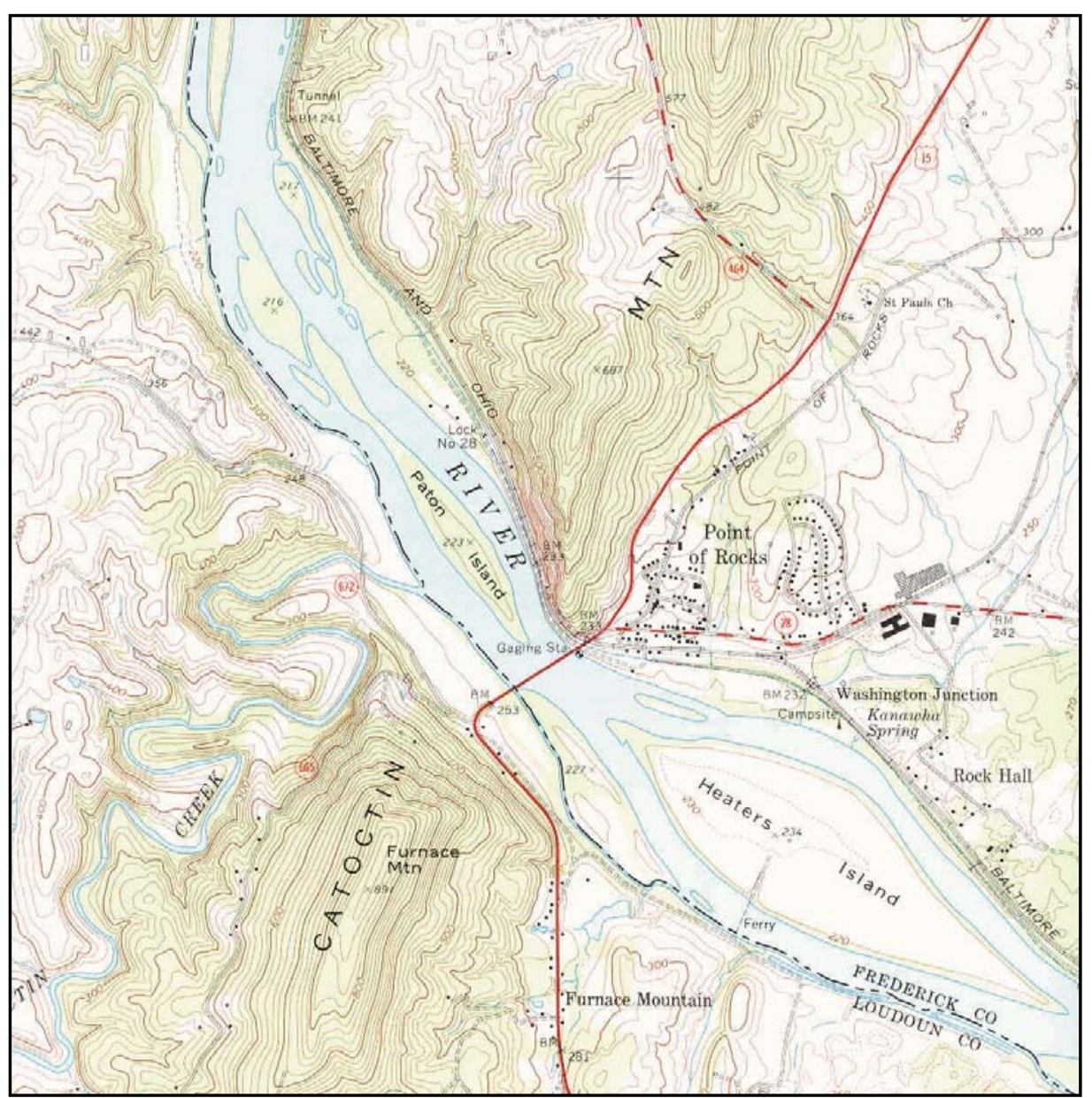

Catoctin Mountain appears on multiple USGS 7.5-minute topographic quadrangle maps. The record for this feature name provides information from the Geographic Names Database (accessible at geonames.usgs.gov). 